ROCZNIKI TEOLOGICZNE

Tom LXVIII, zeszyt $8-2021$

DOI: https://doi.org/10.18290/rt21688.3

KS. BOGUSŁAW MIGUT

\title{
KU PEŁNEMU UCZESTNICTWU W EUCHARYSTII W OKRESIE PANDEMII
}

\author{
PARTICIPATION IN THE EUCHARIST AS A SPECIAL CHALLENGE \\ DURING THE PANDEMIC
}

A b s t r a c t. Christian worship is worship modelled on that of Jesus Christ, and in union with Him (cf. Rm. 12:1). Therefore the fullest expression of the worship of the Church is the Eucharist. In it is made sacramentally present the consummate, once-for-all, unique offering of Christ, that is to say, His life of obedience and devotion to the Father, which has its fulfillment in death upon the cross. The participation of the faithful in the Eucharist consists in the following of Jesus in obedience to the Father, that is, in rendering a spiritual offering which Jesus joins to His one offering. Participation in the Eucharist is a special challenge during the pandemic not only due to physical difficulties in participating, but also as regards fullest possible extra-sacramental participation, i.e., long-distance participation. The most important condition is the desire for sacramental participation and union with Christ, that is, spiritual communion. Mass-media transmissions of the Mass are helpful in this. Other essential conditions for such participation are an accompanying desire for ongoing conversion (directing of one's life towards God) and involvement in the life of the Church on various levels. Meditation on the Word of God in the form of lectio divina is to be considered as an especial pillar of this extra-sacramental participation. The faithful have the right to read the books of Sacred Scripture in any order. The most ecclesial reading of the Bible, however, is that which is geared toward the daily Eucharist. The individual believer is nourished by this word which is addressed to the entire church on a given day.

Keywords: The Eucharist; Participation in the Eucharist; Participatio Actuosa; Non-sacramental participation in the Eucharist.

Ks. prof. dr hab. Bogusław Migut - Katedra Teologii Liturgii, Katolicki Uniwersytet Lubelski Jana Pawła II; adres do korespondencji: Al. Racławickie 14, 20-950 Lublin; e-mail: boguslaw.migut@kul.pl; ORCID: https://orcid.org/0000-0002-8832-5429. 
W czasie gdy uczestnictwo we Mszy niedzielnej czy codziennej zależy wyłącznie od woli wierzących, namysł nad uczestnictwem w Eucharystii skupia się wyłącznie na zasadach uczestnictwa w jej sprawowaniu. W okresie pandemii, która zagraża zdrowiu, a nawet życiu, oprócz ogólnych zasad uczestnictwa w Eucharystii należy pójść dalej, ukazując możliwości uczestnictwa w zbawczym Misterium Chrystusa w komunii z Kościołem poza zgromadzeniem liturgicznym. Pytaniem, na które będzie jednak należało odpowiedzieć jest to, do jakiego stopnia takie uczestnictwo jest możliwe i co należy uczynić, by mogło ono być jak najpełniejsze. Zagadnienie to posiada nie tylko wymiar pastoralny, ale też głęboko teologiczny i tak zostanie tu przedstawione.

Postulat odnowy uczestnictwa w liturgii, a zwłaszcza w Eucharystii pojawia się w całym ruchu liturgicznym, tak w pierwszej jego fazie, nazywanej przez Theodora Mass-Ewerda epoką Prospera Guérangera ${ }^{1}$, jak i w drugiej, nazwanej epoką Lamberta Beauduina ${ }^{2}$. Mass-Ewerd zwraca uwagę, że pierwszy etap był skupiony na życiu monastycznym, a drugi na liturgii parafialnej, przez co w większym stopniu został on ukierunkowany na wiernych świeckich, to oba te etapy charakteryzowała troska o odnowę i pogłębienie uczestnictwa $\mathrm{w}$ liturgii ${ }^{3}$. Taki też cel przyświeca motu proprio Piusa X Tra le sollecitudini z 22 listopada $1903^{4}$, poświęconemu muzyce kościelnej, uznawanemu za faktyczny początek ruchu liturgicznego w Kościele. Papież zaznacza na samym wstępie, że wśród rozlicznych trosk Urzędu Pasterskiego największą jest niewątpliwie troska o liturgię i udział w niej. Ożywienie udziału w liturgii miało się dokonać poprzez przystępowanie do Komunii św., na co wskazuje dekret Piusa X Sacra Tridentina Synodus z 20 grudnia $1905^{5}$. Papież podkreśla mocno, że Komunia św. jest wyrazem pełnego uczestnictwa we Mszy.

\footnotetext{
${ }^{1}$ Jego główne dzieło w tym zakresie: Prosper Guéranger, Explication des prières et des cérémonies de la Sainte Messe: d'après des notes recueillies aux conférences (Bruxelles: Association Saint-Jérôme, 1985).

${ }^{2}$ Por. Lambert Beauduin, La piété de l'Église (Louvain: Abbaye du Mont-César, 1914); Modlitwa Kościoła, tłum. pol. Stefan Koperek (Kraków: PTT, 1987).

${ }^{3}$ Por. Theodor Mass-Ewerd, Liturgie und Pfarrei: Einfluß der liturgischen Erneuerung auf Leben und Verständnis der Pfarrei im deutschen Sprachgebiet (Paderborn: Bonifacius, 1965), 41-46.

${ }^{4}$ AAS 36(1903-04): 387-395; http://www.vatican.va/content/pius-x/la/motu_proprio/docu ments/hf_p-x_motu-proprio_19031122_sollecitudini.html (DOS 12.03.2021).

${ }^{5}$ ASS 38(1906): 400-404; tłum. pol. w Eucharystia w wypowiedziach Papieży i innych dokumentach Stolicy Apostolskiej XX w., red. Romuald Rak (London: KOW Veritas, 1987), 31-36.
} 
Wezwanie do czynnego uczestnictwa wiernych w liturgii powtarza się w Sacrosanctum Concilium jak refren lub wezwanie litanii: „Módl się za nami”, co zauważa S. Czerwik ${ }^{6}$. Pojawia się ono w tym dokumencie wielokrotnie i jest określane w różnych punktach jako świadome, czynne, społeczne, pełne, wewnętrzne i zewnętrzne, pobożne, doskonałe, owocne, a ma polegać ono na pełnym zharmonizowaniu ciała i duszy wiernych ze struktura i treścią czynności liturgicznych. Czerwik odnosi to do zasady zaczerpniętej $\mathrm{z}$ reguły św. Benedykta, która brzmi: ,ut mens nostra concordet voci nostrae", czyli zgodności słów i myśli ${ }^{7}$.

\section{ODKRYĆ ISTOTE UCZESTNICTWA W EUCHARYSTII}

Uczestnictwo w Eucharystii można i należy rozpatrywać na wielu płaszczyznach. Najpełniej można je wyprowadzić z tego, czym Eucharystia jest, a tym samym z jej celowości. Eucharystia posiada ten sam cel, który ma Kościół jako Mistyczne Ciało Chrystusa, a jest nim zjednoczenie ludzi z Bogiem na drodze komunii z Chrystusem, a w Chrystusie ze wspólnotą międzyludzką. Komunia ta zostaje zapoczątkowana na ziemi, a osiągnie swe spełnienie w Królestwie Niebieskim. Eucharystia w powyższym sensie buduje Kościół w ten sposób, że będąc darem samego Chrystusa jest wybraną przez Niego droga zjednoczenia wierzących z Nim, a w Nim między sobą (zjednoczenie międzyludzkie). Zjednoczenie to ma na celu jednoczenie ludzi z Bogiem Ojcem poprzez nieustanną odnowę posłuszeństwa wobec Ojca, na wzór Jego Syna i w komunii z Jego Synem. Komunia ta jest możliwa nie tylko dzięki woli i wysiłkowi samego wierzącego, ale jej sprawcą jest Duch Święty, który dopełnia dzieła Chrystusa na ziemi.

Z ukazanej celowości Eucharystii wypływa główna zasada uczestnictwa w niej. W największym skrócie można stwierdzić, że od strony człowieka polega ono na zjednoczeniu z Chrystusem i wzbudzeniu w sobie pragnienia podporządkowania swego życia Bogu. Trwałość tego zjednoczenia i pragnienia życia dla Boga, które charakteryzowało także całe życie Jezusa Chrystusa, jest natomiast owocowaniem uczestnictwa w Eucharystii w życiu codziennym. Adhortacja $\mathrm{Sa}$ cramentum Caritatis, powołując się na wcześniejsze nauczanie Kościoła, zwła-

\footnotetext{
${ }^{6}$ Por. Stanisław Czerwik. „Wprowadzenie do Konstytucji o liturgii świętej”, w Sobór Watykański II. Konstytucje, dekrety, deklaracje (Poznań: Pallotinum, 2012), 45-46.

7 Por. tamże, 46.
} 
szcza Konstytucję o Liturgii (KL 14-20; 30-31; 48-49), ujmuje uczestnictwo jako kształtowanie przez słowo Boże, posilanie się przy stole Ciała Pańskiego i wyrażanie Bogu wdzięczności. Przede wszystkim jednak uczestnictwo polega na tym, by wierni ofiarowali Bogu ,niepokalaną hostię nie tylko przez ręce kapłana, lecz także razem z nim, uczyli się samych siebie składać w ofierze dzień po dniu, by za pośrednictwem Chrystusa doskonalili się w zjednoczeniu z Bogiem i wzajemnie z sobą"8. Sobór Watykański II słusznie położył szczególny nacisk na czynne, pełne i owocne uczestnictwo całego Ludu Bożego w celebracji eucharystycznej (KL 14-20; 30-31; 48-49). Niekiedy uwidocznia się pewne niezrozumienie znaczenia tegoż uczestnictwa.

Uczestnictwo zaangażowane - czynne uczestnictwo, którego pragnął Sobór, winno być rozumiane w sensie głębszym, począwszy od większej świadomości tajemnicy, która jest celebrowana, aż do jej związku z codzienną egzystencją. Uczestnictwo zaangażowane (participatio actuosa) nie oznacza jedynie prostej zewnętrznej aktywności podczas celebracji. Eucharystia nie jest bowiem horyzontalnym zebraniem wiernych, ani też katechezą służącą do pouczenia wiernych. Święta liturgia, choć zawiera bogatą treść do pouczania wiernych, jest przede wszystkim kultem Ojca przez Chrystusa w Duchu Świętym (por. KL 33).

Tym, co wiąże się z uświęcającym i kultycznym charakterem Eucharystii, jest jej wymiar ofiarniczy. Natomiast podstawowym pojęciem pozwalającym uchwycić uczestnictwo w Eucharystii jako udział w ofierze Chrystusa i Kościoła jest pojęcie „ofiary duchowej”. Wypełnia ona najpierw ziemskie życie Jezusa stając się obecnie wyzwaniem dla życia chrześcijańskiego, a tym samym dla jego uczestnictwa w Eucharystii. Istnieje wiele interpretacji pojęcia „ofiara duchowa”, ale najprościej można go wyjaśnić przez odwołanie się do życia Jezusa Chrystusa i Jego nauczania, zawartego w czwartym rozdziale Ewangelii Jana oraz do Pawłowego nawoływania, aby chrześcijanie traktowali swe życie jako ofiarę ku czci Boga. Jezus w rozmowie z Samarytanką stwierdza najpierw, że kult Boga, który On zapoczątkowuje, jest kultem „w Duchu i prawdzie" (J 4,24). Oznacza to, że kult chrześcijański jest kultem serca, czyli jest kultem duchowym, ale jest też kultem w Duchu Świętym oraz w prawdzie, czyli w Chrystusie, przez Chrystusa i na wzór Chrystusa. Wzór ten pokazuje Jezus nieco dalej, gdy stwierdza: „Moim pokarmem jest wypełnić wolę Tego, który Mnie posłał, i wykonać Jego dzieło" (J 4,34). Pełnienie woli Ojca jest dla niego wszystkim, treścią i pokarmem życia, ale też naj-

\footnotetext{
${ }^{8}$ Benedykt XVI, Adhortacja Sacramentum Caritatis (22.02.2007), 52.
} 
doskonalszym sposobem kultu Ojca. Św. Paweł, mając przed oczyma taką postawę Jezusa, zwraca się do wierzących: „A zatem proszę was, bracia, przez miłosierdzie Boże, abyście dali ciała swoje na ofiarę żywą, świętą, Bogu przyjemną, jako wyraz waszej rozumnej służby Bożej” (Rz 12,1). „Ro-

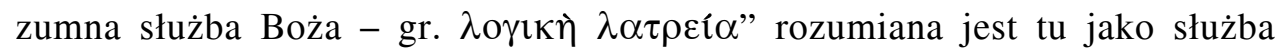
Bogu, czyli kult w łączności z Chrystusem jako Logosem i na Jego wzór, czyli w szukaniu i wypełnianiu woli Ojca. Kult Ojca „w łączności z Logosem", który jako jedyny w doskonały sposób uwielbił Ojca, wypełniając Jego wolę oraz „na wzór Logosu”, czyli w ciągłym poszukiwaniu woli Ojca i pragnieniu spełniania tej woli jest najprostszą i najbardziej wymowną definicją Eucharystii. Łączność z Logosem ma wymiar sakramentalny, ale „kult na wzór Logosu" odnosi się do konkretu życia chrześcijańskiego.

Uczestnictwo w Eucharystii polega więc od strony chrześcijanina na składaniu ofiary duchowej w zjednoczeniu z Chrystusem i z Jego ofiara z samego siebie złożoną raz na zawsze, a uobecnioną „tu i teraz” na sposób sakramentalny ${ }^{9}$. Chrześcijanie nie posiadają innych ofiar, poza jedyną, złożoną raz na zawsze ofiara życia Jezusa z jej wymiarem duchowym i krwawym oraz tą, którą jest ich własne życie podporządkowane Bogu. Szukanie i wypełnianie woli Ojca jest ofiarą duchową, która ma być składana także w każdej Eucharystii. Bez niej Eucharystia stanowiłaby tylko uobecnianie samej ofiary Chrystusa, a tym samym byłaby oderwana od życia wierzącego i nie byłaby ofiara chrześcijanina. W takiej sytuacji Eucharystia stałaby się wyłącznie kultem, jaki Jezus Chrystus składa Ojcu, ale nie byłaby kultem, jakim chrześcijanie wraz z Chrystusem uwielbiają Ojca. Ofiara duchowa wpisana jest w życie chrześcijańskie, w jego wymiar moralny i duchowy. Katechizm Kościoła Katolickiego utożsamia życie moralne z kultem duchowym, łącząc je też z Ofiarą eucharystyczną. „Składamy «ciała swoje na ofiarę żywą, świętą, Bogu przyjemną» (Rz 12,1) w Ciele Chrystusa, które tworzymy, i w komunii z Ofiarą eucharystyczną. [...] Życie moralne, podobnie jak całość życia chrześcijańskiego, ma swoje źródło i swój szczyt w Ofierze eucharystycznej"10.

\footnotetext{
${ }^{9}$ Por. Bogusław Migut, „Eucharystia jako ofiara w świetle Katechizmu Kościoła Katolickiego i wprowadzeń do wybranych ksiąg liturgicznych”, w Eucharystia-źródto, szczyt i życie. Tydzień Eklezjologiczny 2004, red. Jan Budzyński, Paweł Łukasik, Krzysztof Mielcarek [W trosce o Kościół, V] (Lublin: Wydawnictwo KUL, 2005), 46-49.

${ }^{10}$ KKK 2031; por. Jan Szlaga, „Eucharystia - ofiara Nowego Przymierza”, w Eucharystia - miłość i dziękczynienie, red. Walerian Słomka, Antoni J. Nowak [Homo meditans IX] (Lublin: TN KUL, 1992), 19; Wacław Świerzawski, Eucharystia Chrystusa i Kościoła (Kraków: WAM, 1983), 94-95.
} 
Ofiara duchowa jako wypełnienie woli Ojca, czyli powierzenie mu drogi zaufanie, całkowite oddanie się Jego miłości, jest ona natomiast możliwa dzięki uczestnictwu w ofierze eucharystycznej ${ }^{11}$.

\section{UCZESTNICTWO W EUCHARYSTII A NAWRÓCENIE}

Uczestnictwa w Eucharystii wręcz nie wolno zamknąć w samym wymiarze obrzędowym, odseparowanym od chrztu i bierzmowania, czyli sakramentalnych źródeł dziecięctwa Bożego i namaszczenia Duchem Świętym, a wcześniej od nawrócenia, które po chrzcie realizuje się w sakramencie pokuty i pojednania. Nie wolno również uczestnictwa w Eucharystii odcinać od całości życia chrześcijańskiego w jego wymiarze indywidualnym i społecznym.

Życie Boże, zrodzone w chrzcie i bierzmowaniu, znajduje swą kontynuację i dopełnienie w Eucharystii. Chrzest staje się niezrozumiały poza Eucharystią, a Eucharystia nie jest w pełni poznawalna bez odniesienia do nawrócenia, które w przypadku osób dorosłych, jako akt o charakterze fundamentalnym dla wiary, znajduje najpierw swe spełnienie w sakramencie chrztu. Po chrzcie nawrócenie znajduje swą sakramentalną formę i realizację w sakramencie pokuty i pojednania. Nawrócenie jest nieskuteczne, a nawet pozorne, jeśli nie przyczynia się najpierw do chrzcielnego włączenia do Kościoła i nieustannego powracania w sakramencie pokuty do komunii z Chrystusem i z Kościołem utraconej przez grzech. Bez stałego nawracania się jego członków i dostępu do Eucharystii Kościół byłby tylko wspólnotą w wymiarze horyzontalnym. W tak postrzeganym Kościele ewangelizacja, a następnie katecheza byłyby tylko daleką od życia teorią, nauką religijnego savoir-vivre'u, programem szkolnego nauczania, nie prowadząc do nawrócenia i początkowej (chrzest) lub wtórnej (pokuta) inicjacji w solidne kościelne środowisko wiary. Można zatem powiedzieć, że w chrzcie i pokucie rozpoczyna się Eucharystia, a w Eucharystii podtrzymywany jest chrzest i nieustanne nawrócenie (pokuta). $\mathrm{Z}$ tego najważniejszego związku pomiędzy sakramentami chrztu, pokuty i Eucharystii płynie całe życie Kościo-

\footnotetext{
${ }^{11}$ KKK 2100; por. Roch A. Kereszty, Wedding Feast of the Lamb: Eucharistic Theology from a Historical, Biblical, and Systematic Perspective (Chicago/Mundelein: Hillenbrand Books, 2004), 168-209.
} 
$\mathrm{ła}^{12}$. Jest on także ważną podstawą do zrozumienia i zastosowania istoty uczestnictwa w Eucharystii w każdej sytuacji i okoliczności.

Ewangelia nieustannie urzeczywistnia się w chrzcie i w Eucharystii i te najważniejsze sakramenty Nowego Testamentu są ściśle powiązanymi i nierozerwalnymi fundamentami chrześcijańskiej egzystencji. Eucharystia nie ma żadnego znaczenia bez chrztu, a chrzest nie znajduje swej realizacji bez Eucharystii i bez słowa Bożego, które w niej nabiera szczególnego wymiaru sakramentalnego. Oba sakramenty pozwalają żyć życiem Jezusa Chrystusa, który zjednoczył się z każdym człowiekiem. Są one komunią-zjednoczeniem z Bogiem w Kościele ${ }^{13}$. Żadna liturgia nie przynależy do samego rdzenia chrześcijaństwa, jeśli nie jest sprawowana w ramach dialektycznego napięcia między chrztem i Eucharystią jako dwoma zawiasami, na których zawieszona jest cała ekonomia sakramentalna Kościoła, czyli ,posługa jednania”, o której pisze św. Paweł (2 Kor 5,18-20). Dzieje się tak dlatego, że radykalne kryterium krzyża znajduje się w centrum Ewangelii Jezusa Chrystusa, warunkując wzajemnie śmierć i życie. Celebracja liturgiczna w oderwaniu od życia, a tym samym bez trudu nawrócenia, jest rodzajem ozdobnika i tanią propagandą. Chrzest i Eucharystia zakładają wysiłek nawrócenia i przemiany, stąd w sposób szczególny łączą życie ludzkie z trudem życia, męki i śmierci Jezusa, przypominając i aktualizując mękę Jezusa jako konieczny warunek dziękowania Bogu za jego dobroć i ostateczne zwycięstwo ${ }^{14}$. W tym sensie można przywołać twierdzenie Josefa Piepera, że tylko dojrzała osoba, która godzi się na wysiłek i na ciagłe obumieranie, jest zdolna do prawdziwego odpoczynku i świętowania ${ }^{15}$. Chrzest, którego kontynuacją i aktualizacją jest sakrament pokuty oraz Eucharystia są „trudnymi sakramentami”, gdyż zakładają nawrócenie jako podporządkowanie życia Bogu. Ze stwierdzeń tych należy wyprowadzić wniosek, że podjęcie trudu nawrócenia i przemiany życia jest realizacją przymierza chrzcielnego, które dopełnia się w komunii eucharystycznej, także tej duchowej, gdy niemożliwa jest komunia sakramentalna.

\footnotetext{
12 Por. Aidan Kavanagh, The Shape of Baptism: The Rite of Christian Initiation (Collegeville (MN): Liturgical Press, 1978), 122; Bogusław Migut, „The Eucharist as a Sacrament of Christian Initiation: Historical-Liturgical Aspect", Roczniki Teologiczne 66(2019), 8: 88.

${ }^{13}$ Por. Aidan Kavanagh, ,Relevance and Change in the Liturgy”, Worship 45(1971), 2: 62.

14 Por. tamże; Louis Bouyer, Liturgical Piety (Notre Dame: University of Notre Dame Press, 1955), 158-172.

${ }^{15}$ Por. Josef Pieper, In Tune with the World: A Theory of Festivity, thum. ang. Richard i Clara Winston (New York: Harcourt, Brace and World, 1965), 17-24.
} 


\section{CZY JEST MOŻLIWE UCZESTNICTWO W EUCHARYSTII BEZ FIZYCZNEJ OBECNOŚCI?}

Odpowiedź na to pytanie jest raczej negatywna, gdyż celebracja liturgiczna ze swej natury jest warunkowana między innymi obecnością ludu kapłańskiego, czyli zgromadzeniem się wspólnoty Kościoła. To, czego Jezus dokonał w swoim ciele ludzkim, doczesnym i fizycznym, dokonuje On teraz w swym Ciele mistycznym, czyli w Kościele. Stąd znakiem sakramentalnym nie jest tylko sam znak towarzyszący słowu, ale też znak zgromadzenia.

Uczestnictwo w liturgii tworzy rzeczywistość sakramentu. Sakrament bowiem to nie tylko słowo i znak pochodzący z ustanowienia Chrystusa, czy Kościoła, ale jest to także znak obecności i działania Kościoła jako konkretnego zgromadzenia liturgicznego. Znakiem tym jest celebracja, a właściwie jej uczestnicy, czyli właśnie zgromadzenie liturgiczne. Cielesno-duchowe uczestnictwo w liturgii buduje więc sakrament, gdyż objawia Kościół jako zgromadzenie przy Chrystusie, przy Jego słowie, dając człowiekowi możliwość udziału w jego zbawczym Misterium. Zgromadzenie to, budowane przez samego Chrystusa mocą Ducha Świętego, jest dla wierzących zaszczytem i obdarowaniem. Drugą ważną rzeczą jest to, że uczestnictwo w liturgii buduje życie indywidualne i społeczne. Na pierwszy rzut oka wydaje się czymś oczywistym, że uczestnictwo w liturgii buduje życie indywidualne, ale zaskakuje, że buduje ono również życie społeczne. Wydaje się, że jeżeli już miałoby budować je $\mathrm{w}$ takim wymiarze, to tylko w sensie gromadzenia wierzących $w$ ramach zgromadzenia liturgicznego. Tymczasem liturgia i udział w niej buduje życie ludzkie w aspekcie wspólnotowym, gdyż przemiana indywidualna człowieka dotyka w nim wszystkich wymiarów jego życia i wszystkich jego relacji, prowadząc w ten sposób także do przemiany życia społecznego. W tym sensie liturgia poprzez serce człowieka przemienia również kształt życia wspólnego. Toteż przemiana życia społecznego jest owocem konkretnym, choć nie zawsze łatwo zauważalnym uczestnictwa w liturgii. Człowiek, przemieniony w Eucharystii i żyjący na sposób eucharystyczny, jest żywym sakramentem działania Chrystusa w świecie, czyli też sakramentem Królestwa Bożego na ziemi.

Teologia uczestnictwa w liturgii, w tym przypadku w Eucharystii, wypływa $\mathrm{z}$ relacji liturgii do wiary i Tradycji. Liturgia Kościoła to nic innego, jak wiara tego Kościoła w działaniu na ściśle określonych zasadach i na najważniejszych poziomach jego bytu. Wiara wyraża się w różnych jej przejawach, związanych zarówno z samym bytem człowieka, jak z jego działaniem, ale ostatecznie zawsze jej ostatecznym wyrazem będzie kult Boga. Uczestnictwo 
w liturgii polega na odkryciu, że to nie tylko Kościół gromadzi się, aby wielbić Boga, ale o wiele ważniejszy jest fakt, że w Kościele obecny jest żywy Bóg. Obecność ta nie jest teorią teologiczną, lecz prawdziwą obecnością, która może wpływać na świat i go przemieniać, a przez tę aktywną i rzeczywistą obecność Boga realizuje się szczególnie Jego dar z siebie w swoim Synu przez Ducha Świętego. Bóg nie jest obecny w Kościele zgromadzonym na sprawowaniu Eucharystii jedynie przez wiarę, ale jest obecny rzeczywiście. To Kościół istnieje przez wiarę w Boga, a wiara ta osiąga swoje spełnienie w kulcie Boga. Dlatego uczestnictwo wiernych w liturgii, wiernych oddających cześć i uwielbienie Bogu przez Chrystusa, jest aktem wiary, którego nie można porównać z żadnym innym ${ }^{16}$.

Powracając jednak do pytania o możliwość uczestnictwa w Eucharystii, nie będąc członkiem konkretnego zgromadzenia sprawującego Eucharystię, warto powrócić do istoty uczestnictwa w Eucharystii. Nie wymaga specjalnego ukazywania prawdy o tym, że uczestnictwo fizyczne nie jest możliwe na odległość. Zgromadzenie liturgiczne, jako zgromadzenie Kościoła, nie powinno być opuszczane z błahych powodów. Może ono jednak być zastąpione w nadzwyczajnych sytuacjach, a taką jest niewattpliwie obecna pandemia, uczestnictwem duchowym, czyli uczestnictwem pragnienia i duchową więzią z Tym, który zwołuje zgromadzenie Kościoła i który jest pierwszym Liturgiem i „Sercem” modlącego się Kościoła. Ta więź duchowa obejmuje także pragnienie zjednoczenia w Chrystusie z Kościołem. Ze względu na konkretność i wyrazistość znaku Kościoła pragnienie to winno skupiać się na tym zgromadzeniu Kościoła, w którym zazwyczaj uczestniczymy. Prawda ta wynika z teologii zgromadzenia liturgicznego, ale też z teologii parafii i jej miejsca w Kościele partykularnym i powszechnym.

Uczestnictwo poprzez środki społecznego przekazu wspiera to duchowe pragnienie komunii ze zgromadzonym „tu i teraz” Kościołem na sprawowaniu Eucharystii, ale samo oglądanie czy słuchanie zawsze będzie niewystarczające. Wydaje się, że troska duszpasterska Kościoła w Polsce w ostatnim czasie nadmiernie skupiała się na samym uczestnictwie w transmisji. Brakuje natomiast większego skupienia na uczynieniu takiego uczestnictwa jak najpełniejszym (participatio actuosa) i odpowiadającym misterium Eucharystii.

Wartość uczestnictwa we Mszy św. za pomocą środków przekazu jest nie do przecenienia. Urząd Nauczycielski Kościoła wyraźnie jednak podkreśla, że

\footnotetext{
${ }^{16}$ Por. Aidan Kavanagh, On Liturgical Theology. The Hale Memorial Lectures of SeaburyWestern Theological Seminary 1981 (Collegeville [MN]: Liturgical Press, 1984), 7-8.
} 
ktokolwiek korzysta z transmisji Mszy, powinien wiedzieć, że w normalnych warunkach nie spełnia świątecznego obowiązku. Język obrazu bowiem przedstawia rzeczywistość, ale jej samej nie uobecnia. Transmisja przez radio, telewizję, czy Internet daje ogromną szansę uczestnictwa we Mszy osobom starszym i chorym. Jest szansą uczestnictwa dla wszystkich szczególnie w okresie pandemii. Mimo niewątpliwych wielu dobrodziejstw transmitowanej Mszy trzeba mocno podkreślić, że nigdy nie zastąpi ona uczestnictwa w celebracji eucharystycznej żywego Kościoła, ani też nie zwalnia z pójścia do kościoła osobom zdrowym i sprawnym ${ }^{17}$. Dyspensy od obowiązku uczestnictwa w niedzielnej Eucharystii udzielane przez biskupów na czas pandemii winny być przyjmowane przez wierzących jako wyraz szacunku dla ich zdrowia i życia, ale nie jako zakaz fizycznego uczestnictwa w Eucharystii niedzielnej w żywym zgromadzeniu wiernych. Korzystanie z dyspensy powinno podlegać ciagłemu osądowi wrażliwego sumienia chrześcijanina.

\section{UKIERUNKOWANIE ŻYCIA NA EUCHARYSTIĘ I EUCHARYSTYCZNY STYL ŻYCIA}

W dobie pandemii szczególne zastosowanie ma odpowiednie rozumienie tego, że liturgia jest źródłem i szczytem życia całego Kościoła jak i pojedynczego w Nim chrześcijanina. Chodzi tu o ukierunkowanie życia na celebrację, zgodnie z zasadą podaną przez Sobór. Celem i źródłem życia chrześcijańskiego, które ze swej natury jest częścią życia Kościoła, niezależnie od tego, czy Kościół będzie pojmowany jako Mistyczne Ciało Chrystusa, Communio osób w Chrystusie, czy jako Lud Boży zjednoczony z Chrystusem i przez Niego prowadzony. Celem i źródłem życia chrześcijanina jest realizacja i pogłębianie chrzcielnego daru dziecięctwa Bożego oraz gromadzenie się jako wspólnota dzieci wielbiących Ojca i uczestniczących w Ofierze Syna Bożego (por. KL 10). Celem tego uczestnictwa jest sakramentalna komunia z Bogiem, ukierunkowana na jej spełnienie w komunii eschatologicznej. $\mathrm{Z}$ tego wynika, że budowanie komunii z Bogiem, na każdy możliwy do realizacji sposób, jest warunkiem uczestnictwa w Eucharystii także w sytuacji fizycznej nieobecności w eucharystycznym zgromadzeniu wiernych.

Ukierunkowanie życia na Eucharystię i eucharystyczny styl życia są zawsze wyzwaniem dla chrześcijanina, także wtedy gdy uczestnictwo w cele-

\footnotetext{
${ }^{17}$ Por. Benedykt XVI, Adhortacja Sacramentum Caritatis (22.02.2007), 57.
} 
bracji Eucharystii jest w pełni możliwe. Stają się one jednak szczególnym wyzwaniem w sytuacji braku możliwości fizycznego uczestnictwa w celebracji, choć w oczywisty sposób nie mogą jej zastąpić. Oba te elementy są nierozerwalnie związane z komunią duchową. Komunia duchowa tylko w sytuacjach nadzwyczajnych jest w pełni satysfakcjonująca, stając się „ekwiwalentem” komunii sakramentalnej, gdyż w warunkach „,normalnych” winna ona komunię sakramentalną poprzedzać i jej towarzyszyć. Ukierunkowanie życia na Eucharystię i eucharystyczny styl życia są nierozerwalnie powiązane z uczestnictwem w celebracji, ale w warunkach nadzwyczajnych, w których nie ma możliwości takiego uczestnictwa, stają się one jedynym, choć pozasakramentalnym uczestnictwem w paschalnym Misterium Chrystusa. Uczestnictwo w transmisji Mszy, choć ważne z wyżej wspomnianych powodów, nie jest więc istotą uczestnictwa pozasakramentalnego w niej, gdyż to zakłada odpowiednią postawę wewnętrzną, którą jest właśnie wysiłek ukierunkowywania życia na Eucharystię i wypływjący z Eucharystii styl życia. Jan Paweł II pisał o tym w następujących słowach: „Głoszenie śmierci Pana «aż nadejdzie» (1Kor 11,26) zakłada, iż wszyscy uczestniczący w Eucharystii podejmą zadanie przemiany życia, aby w pewnym sensie stało się ono całe «eucharystyczne»"18. Polega ono na wysiłku w ,polepszaniu egzystencji i zaangażowaniu na rzecz przemiany świata zgodnie z Ewangelią" w perspektywie eschatologicznej ${ }^{19}$.

W nawiązaniu do tego, co zostało stwierdzone powyżej na temat postrzegania uczestnictwa w Eucharystii w perspektywie sakramentów chrztu i bierzmowania, a więc $\mathrm{w}$ perspektywie pierwotnego nawrócenia i nieustannego procesu przemiany życia (gr. $\mu \varepsilon \tau \alpha \nu o l \alpha$ ), warto dostrzec wskazania Benedykta XVI zawarte w adhortacji posynodalnej Sacramentum Caritatis. Wskazania te odnoszą się do uczestnictwa sakramentalnego, czyli fizycznego w Eucharystii, ale w warunkach nadzwyczajnych wyznaczają one sposoby uczestnictwa pozasakramentalnego. Pierwszym sposobem i warunkiem takiego uczestnictwa jest „duch ciągłego nawracania się”, który jest wręcz wyznacznikiem głębi udziału w Eucharystii. Mówiąc o głębi uczestnictwa, nie chodzi więc w pierwszej kolejności o głębię pojmowania tajemnicy Eucharystii, ani też o obrzęd i formę jej sprawowania, ale o cała postawę nawracania się i włączenia procesu nawracania w Eucharystię. „Nie można oczekiwać czynnego uczestnictwa w liturgii eucharystycznej, jeśli przystępuje się do niej w sposób

\footnotetext{
18 Jan Paweł II, Encyklika Ecclesia de Eucharistia (17.04.2003), 20.

${ }^{19}$ Por. tamże.
} 
płytki, bez stawiania sobie pytań dotyczących własnego życia" ${ }^{20}$. Sprzyja temu skupienie i cisza podczas uczestnictwa, ale też odpowiednie przygotowanie poprzez post $i$, jeśli to jest konieczne, przez spowiedź sakramentalną. Wszystko to bowiem prowadzi do nawrócenia i pojednania z Bogiem „serca”, a przez to uzdalnia do prawdziwego uczestnictwa w sakramencie Eucharystii, także w sposób pozasakramentalny. Ponadto actuosa participatio w Eucharystii jest możliwe tylko wówczas, gdy uczestnik „stara się równocześnie uczestniczyć czynnie w życiu kościelnym w jego całości, w czym mieści się także zaangażowanie misyjne, polegające na wprowadzaniu miłości Chrystusa w życie społeczne" 21 .

Ten ostatni warunek ma wyjątkowo liczne zastosowania w okresie pandemii, gdyż daje ona liczne możliwości zaangażowania w pomoc innym.

\section{KOMUNIA ŚWIEৃTA SAKRAMENTALNA POZA MSZĄ I KOMUNIA DUCHOWA SPEŁNIENIEM CELOWOŚCI EUCHARYSTII}

Komunię człowieka z Bogiem zapoczątkowuje proces nawrócenia i jest on istotnym elementem samego aktu wiary. Następnym etapem budowania komunii jest chrzest, będący w przypadku osoby dorosłej sakramentalnym zwieńczeniem procesu nawrócenia. W nim człowiek staje się dzieckiem Bożym, a w bierzmowaniu zostaje napełniony Duchem Świętym. Oba te sakramenty tworzą jedną całość obdarowania darem dziecięctwa i darem Ducha Świętego, co jest zarazem budowaniem komunii z człowiekiem przez Boga, ale przez nawrócenie jest też świadomym budowaniem komunii z Bogiem przez człowieka. Kolejnym etapem jest Komunia eucharystyczna, w której też spotyka się agápe Boga ze zwracaniem się człowieka ku Bogu, czyli jego nawracaniem. Eucharystia nie ma sensu bez chrztu ani chrzest bez Eucharystii, a obie te rzeczywistości nie mają sensu bez słowa Bożego, będącego nieustannym wezwaniem do nawrócenia. Chrzest i Eucharystia to fundamenty życia chrześcijańskiego, a zarazem fundamenty komunii z Bogiem, a w Bogu między ludźmi. One bowiem najpełniej ukazują wyjątkową osobliwość przejścia chrześcijanina od śmierci do nowego rodzaju życia. Zjednoczenie z Bogiem jest jedynym stanem egzystencji, którym cieszymy się w Jezusie, który stał się jedno z nami w misterium Kościoła przez chrzest i Eucharystię. Dzięki

\footnotetext{
${ }^{20}$ Benedykt XVI, Adhortacja Sacramentum Caritatis, 55.

21 Tamże.
} 
tym sakramentom buduje nieustannie komunię z Bogiem wśród ludzi. Komunia jest więc celem nawrócenia prowadzącego do chrztu, a następnie przez dyscyplinę ascetyczną i kontemplację słowa Bożego, a więc także nawrócenie pochrzcielne, które od strony człowieka jest warunkiem uczestnictwa w celebracji eucharystycznej ${ }^{22}$. Komunia ma wymiar wertykalny i horyzontalny, a w wymiarze wertykalnym należy dostrzec proces odgórny, czyli dar zjednoczenia pochodzący od Boga i oddolny, będący wyrazem nawrócenia.

Różnicą pomiędzy Komunią eucharystyczną (Komunia święta) a innymi rodzajami komunii z Bogiem jest to, że w Eucharystii Jezus udziela się człowiekowi realnie i substancjalnie, czyli człowiek otrzymuje dar komunii z Nim w Jego uwielbionym Ciele i Krwi. Jak zauważa Joseph Ratzinger/Benedykt XVI, powołując się na Janowy termin „godzina Jezusa”, która jest godzina Jego wielkiego przejścia, przemiany, a to bytowe przeobrażenie dokonuje się przez agape. Jest to agape „aż do końca”, co wzmacniają jeszcze słowa Jezusa na krzyżu „dokonało się” - tetelestai (J 19,30). Tym celem (telos), czyli pełnią daru z siebie samego i przeobrażenia całego bytu, jest właśnie oddanie siebie samego aż na śmierć. To uniżenie się i oddanie idzie jeszcze dalej w komunii eucharystycznej i jest ukierunkowane na każdego człowieka indywidualnie, aby uczynić go uczestnikiem zbawienia, a tym samym społeczności odrodzonych w Chrystusie, czyli Kościoła. To udzielanie się Boga w Jezusie jest wychodzeniem z ograniczeń zamkniętej w sobie jednostkowości; jest właśnie ową agape - przełomem wprowadzającym człowieka w sferę boskości $^{23}$. Bez wątpienia można więc powiedzieć, że Komunia św. jest spełnieniem wszystkich rodzajów komunii, jakie mają miejsce podczas sprawowania Eucharystii od wejścia przewodniczącego, przez komunię w słowie Bożym i komunię ofiary. Tę syntetyzującą funkcję Komunii św. można podsumować stwierdzeniem, że to właśnie w niej spełnia się celowość całej Eucharystii.

Komunia św. podczas Mszy nie jest prostym spożywaniem Ciała i Krwi Chrystusa. Takie ujmowanie ocenić należy jako mechaniczne i rytualistyczne, gdyż sama natura Eucharystii zakłada integralność wiary, celebracji i życia uczestników (ethos). Chodzi tu o otrzymywanie komunii z Chrystusem w chlebie i winie, czyli w Jego Ciele i Krwi. Otrzymanie komunii w chlebie, który na początku był znakiem ofiary duchowej chrześcijanina, a teraz stał się Ciałem Pańskim, oznacza, że wewnętrzna ofiara uczestnika celebracji

\footnotetext{
${ }^{22}$ Por. Kavanagh, ,Relevance and Change in the Liturgy,” 62.

${ }^{23}$ Por. Joseph Ratzinger/Benedykt XVI, Jezus z Nazaretu, cz. 2: Od wjazdu do Jerozolimy do Zmartwychwstania, tłum. pol. Wiesław Szymona (Kielce: Jedność, 2011), 67.
} 
zostaje potwierdzona (uczyniona ważną) dzięki uczestnictwu w Ofierze Chrystusa. Stąd wypływa potrzeba przyjmowania komunii podczas uczestnictwa we Mszy św. z darów aktualnie w niej konsekrowanych. Chociaż każda Msza jest celebrowaniem jednej i tej samej ofiary Chrystusa, niepodlegającej kategoriom miejsca i czasu, to jednak ze względu na uczestników składających swe duchowe ofiary w konkretnym miejscu i czasie sakramentalne uobecnienie tej ofiary jest za każdym razem inne. Komunia jest nie tylko sakramentalnym zjednoczeniem z Chrystusem, lecz także udziałem w Jego Ofierze. Ofiara jest wtedy pełna, gdy stanowi moralne zjednoczenie $\mathrm{z}$ ofiarą Chrystusa przez udział we Mszy, a następnie prowadzi do zjednoczenia sakramentalnego przez spożywanie hostii podczas tej Mszy konsekrowanej ${ }^{24}$. Przyjmowanie Komunii z hostii konsekrowanych podczas innej Mszy bądź przyjmowanie jej poza Mszą jest zjednoczeniem z Chrystusem, ale nie tworzy pełnej jedności sakramentalno-osobowej uczestnictwa w Jego Ofierze.

Każda Komunia św. łącznie z tą poza Mszą św., przy uwzględnieniu wyjątkowości i pełni Komunii z darów konsekrowanych podczas Eucharystii, w której uczestniczą osoby ją przyjmujące, jest jednak karmieniem się owocem Mszy świętej. Pierwszym i podstawowym sposobem uczestnictwa we Mszy św. bez fizycznej obecności w zgromadzeniu eucharystycznym jest sakramentalne przyjęcie Komunii świętej poza Mszą świętą. Wskazuje na to Benedykt XVI, gdy stwierdza, że chorzy wzmacniając przez Komunię związek z „Chrystusem ukrzyżowanym i zmartwychwstałym, będą mogli czuć się w pełni egzystencjalnie włączeni w życie i misję Kościoła, poprzez ofiarę z własnego cierpienia, w zjednoczeniu z ofiarą naszego Pana" ${ }^{25}$. Wydaje się, że tę zasadę można także rozciągnąć na osoby niemogące uczestniczyć w Eucharystii z powodu pandemii. Takie znaczenie Komunii potwierdza też wprowadzenie teologiczno-pastoralne do księgi Komunia święta i kult tajemnicy eucharystycznej poza Msza święta, gdy stwierdza, że „Zasadniczym i pierwotnym celem przechowywania Eucharystii poza Mszą świętą jest udzielanie Wiatyku. Drugorzędnymi zaś celami są: rozdawanie Komunii świętej i adoracja naszego Pana Jezusa Chrystusa obecnego w Sakramencie. Zachowywanie świętych postaci dla chorych wytworzyło chwalebny zwyczaj adorowania tego niebiańskiego posiłku przechowywanego w świątyniach"26. Udzie-

24 „Zaleca się, aby wiernym udzielano Komunii św. z Hostii konsekrowanych podczas tej Mszy św., w której uczestniczą, gdyż wtedy Komunia ukazuje się wyraźniej jako udział w aktualnie składanej ofierze" (KL 27).

25 Benedykt XVI, Adhortacja Sacramentum Caritatis (22.02.2007), 58.

${ }^{26}$ Komunia święta i kult tajemnicy eucharystycznej poza Msza święta. Dostosowane do 
lanie Komunii św. chorym poza Mszą jest owocem i przedłużeniem sprawowania Eucharystii i zawsze pozostaje w relacji do niego. Adoracja Eucharystii (Najświętszy Sakrament) została uformowana przez Komunię chorych i osób, które nie mogą uczestniczyć we Mszy. Łatwo stąd wyciągnąć wniosek, że „najdoskonalszą” Komunią jest ta, która jest przyniesiona choremu, czy osobie nie mogącej w niej uczestniczyć fizycznie podczas pandemii, która uczestniczyła w tej Mszy w inny sposób, np. poprzez transmisję.

W przypadku braku możliwości uczestnictwa w Komunii poza Mszą pozostaje Komunia duchowa jako Komunia pragnienia. Komunia duchowa, czyli zjednoczenie z Chrystusem osiągane przez pragnienie przyjęcia Chrystusa eucharystycznego, jest zjednoczeniem z Chrystusem za pomocą wiary, „która działa przez miłość" (Ga 5,6). Podczas Mszy winno ono poprzedzać komunię sakramentalną, towarzyszyć jej, a niekiedy, ze względu na fizyczną lub duchową niemożność komunii sakramentalnej, ją zastępować. Jan Paweł II w encyklice poświęconej Eucharystii wyraźnie przypomina nauczanie na temat Komunii św. duchowej i jej więzi z Komunią sakramentalną. Znamienne, że w krótkim tekście znalazły się dwa odniesienia do obu chrześcijańskich tradycji, wschodniej i zachodniej. Pierwsze zdanie z wypowiedzi Papieża jest cytatem z czternastowiecznego teologa bizantyńskiego, Mikołaja Cabasilasa: „w Eucharystii w odróżnieniu od każdego innego sakramentu tajemnica komunii jest tak doskonała, iż prowadzi do szczytu wszelkich dóbr: to tu znajduje swój kres wszelkie ludzkie pragnienie, ponieważ tu otrzymujemy Boga i Bóg wchodzi w doskonałe zjednoczenie z nami”"27. Nawiązując zaś do zachodniej tradycji papież stwierdza: „Warto pielęgnować w duszy stałe pragnienie Sakramentu Eucharystii. Tak narodziła się praktyka «komunii duchowej», szczęśliwie zakorzeniona od wieków w Kościele i zalecana przez świętych mistrzów życia duchowego. Św. Teresa od Jezusa pisała: «Kiedy nie przystępujecie do Komunii i nie uczestniczycie we Mszy św., najbardziej korzystną rzeczą jest praktyka komunii duchowej [...] Dzięki niej obficie jesteście naznaczeni miłością naszego Pana»"28. Skoro komunia duchowa jest komunia pragnienia, to należy ją postrzegać w perspektywie nawrócenia. Oznacza to, że ten rodzaj komunii musi łączyć się ściśle z osobistą wiarą i z życiem.

\footnotetext{
zwyczajów diecezji polskich (Katowice: Księgarnia św. Jacka, 1985), nr 5.

${ }^{27}$ Jan Paweł II, Encyklika Ecclesia de Eucharistia, 34.

28 Tamże.
} 


\section{SŁOWO BOŻE SAKRAMENTALNYM POKARMEM ŻYCIA CHRZEŚCIJAŃSKIEGO}

Uczestnictwo w transmisji Mszy św. nie jest istotą uczestnictwa pozasakramentalnego także ze względu na możliwość karmienia się słowem Bożym, które jest możliwe także poza fizyczną obecnością na Eucharystii. Zwrócenie uwagi na ten aspekt wypływa z konieczności zaakcentowania szczególnego znaczenia słowa Bożego w duchowości chrześcijańskiej, gdyż jest ono najważniejszym jej pokarmem. Chrześcijanie mają szukać w Biblii podstawowego pokarmu dla swego życia duchowego. Nie powinni jednak posługiwać się Biblią jak martwą literą, w którą ich indywidualna interpretacja miałaby dopiero tchnąć nowe życie. Mają korzystać z niej tam, gdzie ożywia ją nieustannie obecność Tego, który ją wypowiedział, gdzie działa Duch Święty, który ją natchnął. Choć już sama litera Biblii jest widzialnym znakiem i „sakramentem" słowa Boga, to jednak prawdziwie sakramentalnego wymiaru nabiera ona w liturgii i przez liturgię, w której swe słowa wypowiada sakramentalnie obecny Liturg historii i wszechświata, Jezus Chrystus.

Jedynie w Kościele, który jest Ciałem Chrystusa, żywe Słowo Boże w Chrystusie nie przestaje być pośród nas obecne, nie przestaje aktualnie do nas przemawiać. Jedynie w Ciele Chrystusa nie przestaje mieszkać Duch Chrystusowy, jako Duch zawsze ożywiający. Doświadczamy tego w szczególny sposób podczas sprawowania liturgii, gdyż zgromadzenie liturgiczne Kościoła jest zgromadzeniem Ludu Bożego, zwołanym przez samego Boga przede wszystkim dla słuchania Jego Słowa ${ }^{29}$.

Sakramentalny wymiar słuchania słowa Bożego w liturgii, na zgromadzeniu Kościoła, jest kontynuacją misterium Chrystusa, który zjednoczył wszystkich w sobie i ostatecznie zjednoczy w perspektywie eschatologicznej. Jezus Chrystus jest bowiem wypełnieniem budowania ludu przez Boga w Starym Testamencie. Za modelowe należy tu uznać zwołanie Ludu Bożego pod Synajem dla zawarcia przymierza. Trzeba zwrócić uwagę, że to zwoływanie Ludu Bożego dla słuchania Bożego Słowa nie jest czymś sztucznym, co realizowałoby się jakby już po fakcie, by przywracać młodość dokumentowi, który się zestarzał. Przeciwnie - jest to normalna droga, na której powstawały, a następnie zostały zebrane teksty biblijne; droga, na której powinny one zawsze być przyjmowane tak, jak zostały dane. Dla przekonania się o tym wystarczy

29 Por. Louis Bouyer, Wprowadzenie do życia duchowego. Zarys teologii ascetycznej i mistycznej, tłum. L. Rutkowska (Warszawa: PAX, 1982), 16-17. 
rozważyć decydujące momenty w dziejach Ludu Bożego, będące równocześnie decydującymi momentami w historii biblijnej, tak jak ona sama nam to przedstawia. Żywym głosicielem Słowa jest zawsze Bóg pośrodku Kościoła i taki sposób głoszenia posiada najgłębszy wymiar sakramentalny ${ }^{30}$.

Wniosek z tego płynie taki, że sakramentalność słowa Bożego w Kościele jest stopniowalna i w pewnym sensie „rozciagliwa” od jego sakramentalności w Eucharystii, przez sakramentalność w sprawowaniu innych sakramentów, Liturgię Godzin, celebracje liturgiczne słowa Bożego (tzw. nabożeństwa słowa Bożego), lectio divina, modlitwę osobistą, a nawet formę pobożności ludu chrześcijańskiego, jaką jest różaniec, będący rozważaniem misteriów Chrystu$\mathrm{sa}^{31}$. Prawda ta ma zastosowanie w możliwości pozasakramentalnego uczestnictwa w Eucharystii przez różne formy karmienia się słowem Bożym, które Chrystus kieruje w konkretnym dniu, w konkretnej celebracji do Kościoła. Podkreśla to także posynodalna adhortacja na temat słowa Bożego: „W pewnym sensie modlitewna lektura, osobista i wspólnotowa, powinna zawsze mieć odniesienie do celebracji eucharystycznej" ${ }^{32}$. Choć lektura Pisma św. może obejmować dowolną jego część w dowolnym czasie, to najbardziej eklezjalne, a zarazem ukierunkowane na codzienną Eucharystię rozważanie Pisma odnosi się do czytań biblijnych danego dnia, konkretnego obchodu liturgicznego.

\section{BIBLIOGRAFIA}

Beauduin, Lambert. La piété de l'Église. Louvain: Abbaye du Mont-César, 1914; tłum. pol. Stefan Koperek. Modlitwa Kościota. Kraków: PTT, 1987.

Bouyer, Louis. Liturgical Piety. Notre Dame: University of Notre Dame Press, 1955.

Bouyer, Louis. Wprowadzenie do życia duchowego. Zarys teologii ascetycznej i mistycznej. tłum. L. Rutkowska. Warszawa: PAX ,1982.

Czerwik, Stanisław. „Wprowadzenie do Konstytucji o liturgii świętej”. W Sobór Watykański II. Konstytucje, dekrety, deklaracje, 25-47. Poznań: Pallotinum, 2012.

Gueranger Prosper. Explication des prières et des cérémonies de la Sainte Messe: d'après des notes recueillies aux conférences. Bruxelles: Association Saint-Jérôme, 1985.

Kavanagh, Aidan. „Relevance and Change in the Liturgy”. Worship 45(1971), 2: 58-72.

Kavanagh, Aidan. The Shape of Baptism: The Rite of Christian Initiation. Collegeville (MN): Liturgical Press, 1978.

\footnotetext{
30 Por. tamże, 27-31.

31 Por. tamże, 31-76.

32 Benedykt XVI, Adhortacja Verbum Domini (30.09.2010), 86.
} 
Kavanagh, Aidan. On Liturgical Theology: The Hale Memorial Lectures of Seabury-Western Theological Seminary 1981. Collegeville (MN): Liturgical Press, 1984.

Kereszty, Roch A. Wedding Feast of the Lamb: Eucharistic Theology from a Historical, Biblical, and Systematic Perspective. Chicago/Mundelein: Hillenbrand Books, 2004.

Mass-Ewerd, Theodor. Liturgie und Pfarrei: Einflu $\beta$ der liturgischen Erneuerung auf Leben und Verständnis der Pfarrei im deutschen Sprachgebiet. Paderborn: Bonifacius, 1965.

Migut, Bogusław. „Eucharystia jako ofiara w świetle Katechizmu Kościoła Katolickiego i wprowadzeń do wybranych ksiąg liturgicznych”. W Eucharystia - źródto, szczyt i życie. Tydzień Eklezjologiczny 2004, red. Jan Budzyński, Paweł Łukasik, Krzysztof Mielcarek. 23-49 [W trosce o Kościół V]. Lublin: Wydawnictwo KUL, 2005.

Migut, Bogusław. „The Eucharist as a Sacrament of Christian Initiation: Historical-Liturgical Aspect". Roczniki Teologiczne 66(2019), 8: 79-90.

Pieper, Josef. In Tune with the World: A Theory of Festivity. tłum. ang. Richard i Clara Winston. New York: Harcourt, Brace and World, 1965.

Ratzinger, Joseph/Benedykt XVI. Jezus z Nazaretu, cz. 2: Od wjazdu do Jerozolimy do Zmartwychwstania. tłum. pol. Wiesław Szymona. Kielce: Jedność, 2011.

Szlaga, Jan. „Eucharystia - ofiara Nowego Przymierza”. W Eucharystia - miłość i dziękczynienie, red. Walerian Słomka, Antoni J. Nowak [Homo meditans IX]. Lublin: TN KUL, 1992.

Świerzawski, Wacław. Eucharystia Chrystusa i Kościoła. Kraków: WAM, 1983.

\section{KU PEŁNEMU UCZESTNICTWU W EUCHARYSTII W OKRESIE PANDEMII}

\footnotetext{
S t r e s z c z e n i e
}

Kult chrześcijański jest kultem na wzór Jezusa Chrystusa i w zjednoczeniu z Nim (Rz 12, 1). Dlatego najpełniejszym wyrazem kultu w Kościele jest Eucharystia. W niej uobecnia się sakramentalnie jedyna i raz na zawsze dokonana ofiara Chrystusa, czyli Jego życie w posłuszeństwie i oddaniu się Ojcu, które ma swe spełnienie w śmierci na krzyżu. Uczestnictwo wiernych w Eucharystii polega na naśladownictwie Jezusa w posłuszeństwie Ojcu, czyli na składaniu duchowych ofiar, które Jezus włącza w swą jedyną ofiarę. Uczestnictwo w Eucharystii jako szczególne wyzwanie w okresie pandemii nie tylko ze względu na trudności z fizycznym uczestnictwem, ale też możliwie pełnym uczestnictwem pozasakramentalnym, czyli na odległość. Pierwszym ważnym warunkiem jest pragnienie sakramentalnego uczestnictwa i zjednoczenia z Chrystusem, czyli komunia duchowa. Pomocne w tym są transmisje Mszy przez środki przekazu. Kolejnymi istotnymi warunkami takiego uczestnictwa są towarzyszące mu pragnienie nieustannego nawracania się (ukierunkowanie życia na Boga) oraz zaangażowanie na różnych płaszczyznach w życie Kościoła. Za szczególny filar takiego uczestnictwa pozasakramentalnego należy uznać rozważnie słowa Bożego w formie lectio divina. Wierny ma prawo czytać księgi Pisma św. w dowolnej kolejności. Jednak najbardziej eklezjalną lekturą Biblii jest ta, ukierunkowana na codzienną Eucharystię. Pojedynczy wierny karmi się tym słowem, które danego dnia jest skierowane do całego Kościoła.

Słowa kluczowe: Eucharystia; uczestnictwo w Eucharystii; participatio actuosa; uczestnictwo pozasakramentalne. 